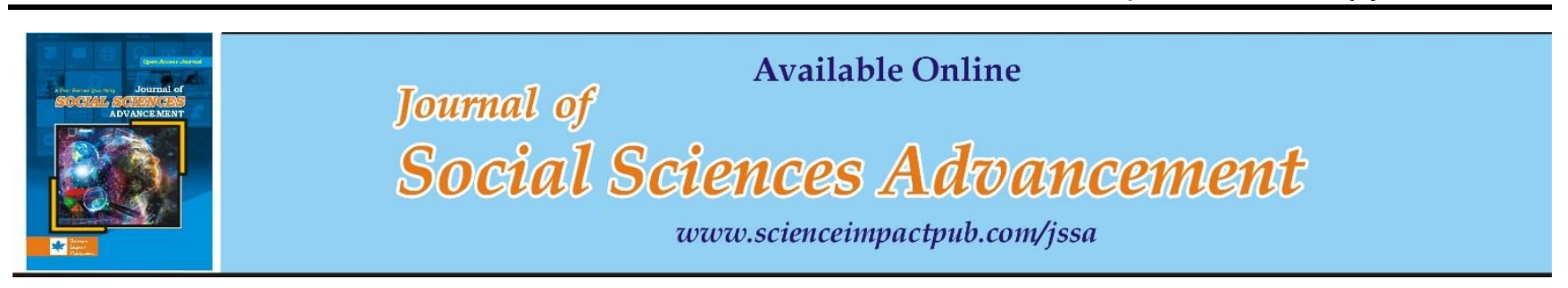

\title{
CONFUCIUS' THOUGHT OF EDUCATION AND INSIGHTS FOR TODAY'S MORAL EDUCATION
}

\author{
Phuc Quang Bao Tran'1, Khalida Parveen¹, Ha Thi Minh Tran² and Anh Quynh Hoang ${ }^{3}$
}

${ }^{1}$ Faculty of Education, Southwest University, Chongqing, China

${ }^{2}$ College of Resources and Environment, Southwest University, Chongqing, China

${ }^{3}$ Department of Chinese Language Studies, Nguyen Tat Thanh University, Vietnam

\begin{tabular}{l} 
ABS T RAC T \\
\hline The present paper attempts to gain insights into Confucius' thought of education and to draw lessons for today's education in \\
the Industry 4.0 era. Confucius, the founder of Confucianism, deserves the world recognition as 'the great exemplary teacher \\
for generations' for his dedication and contributions to education with respect to the role, aim, contents, and pedagogical \\
methods of education. As per Confucius, education should be a universal right and not a privilege only to a group of people in \\
society. The theory of 'no class distinction in education' soon initiates a real revolution in ancient educational thought, availing \\
education to the broad masses of ordinary people. This radical thought is the greatest of all, attesting the importance of equity \\
and equality in education to people from all walks of life. A synthesis of Confucius' thought of education from prior studies, thus, \\
extends the existing literature on education philosophy and expands global understanding of the greatest educational thoughts \\
of all time. These insights have practical implications for today's educational leaders and policymakers alike.
\end{tabular}

Keywords: Confucius; Confucianism; Educational thought; Moral education

Corresponding Author: Phuc Quang Bao Tran, Email: baophucvt2008@gmail.com

(C) The Author(s) 2020.

\section{INTRODUCTION}

At the heart of the whole East, China is a country with more than 5,000 years of history and renowned as one of the cultural cradles of all humanity (Guo, 2009; Zhang, 2015). Over the centuries, China still respectfully treasures rich Asian cultures, traditions, and customs (Beretta et al., 2017; De Mente, 2009). China is now famous all over the world for its mysterious wonders and cultural and natural heritages, namely the Great Wall, the Forbidden City, the Terracotta Army. Truly, the exposure to the outstanding features of Chinese cultural and philosophical studies, i.e. great thoughts of Laozi, Confucius, and Mencius, helps instill great interest in the national cultural identity of China and develop a deeper understanding and cultural exchange of perspectives of great Chinese educational thinkers.

As the most influential philosopher, politician, and educator not only of the Chinese civilization but also of humanity, Confucius is renowned as a shengren (sage), deserving the greatest recognition in ancient China and in modern times as well (Bell \& Chaibong, 2003; Guo, 2009; Tan, 2013; Zhao, 2013). The great master's philosophy exerts a profound influence on Asian culture and education (De Mente, 2009; Guo, 2016; Tang, 2015). Confucianism is the world view pertaining to ethics, politics, and education taught by Confucius and developed by his followers through the ages (Ng, 2009; Tamney \& Chiang, 2002; Tang, 2015). This inspiring school of philosophy embraces teachings, principles, and rules for living, behaving, and thinking that focus on love for humanity, worship of ancestors, respect for elders, selfdiscipline, and conformity to rituals, etc., for the welfare of all humanity (Bell \& Chaibong, 2003; Guo, 2016; Ng, 2009).

Confucius' educational thought is not only valid in the era of his presence but in later times. By the second century BC (140-87 BC), during the reign of Emperor Wu of the Western Han Dynasty, his ideas became the foundation of the state ideology (Guo, 2009; Palmer et al., 2001; Tan, 2013, Tang, 2015). Through the ups and downs in Chinese history, Confucianism has been the mainstream of Chinese traditional thought. Confucius' teachings are still followed and practiced by many followers living in and out of China today, and have shaped, inspired, and influenced the historical flow of thinking in many Asian countries such as Japan, Korea, and Vietnam, etc. (Guo, 2009; Pohl, 1999; Tan, 2013; Tang, 2015; Zhang, 2015). Nowadays, Confucius is widely acknowledged as one of the most influential teachers in the world history of education. Confucius - the founder of Confucianism deserves world recognition as "the great exemplary teacher for generations" for his dedication and contributions to education (Cooney et al., 1993; Guo, 2009; Lin, 2017; Shim, 2008; Tan, 2017; Zhao, 2013).

The present paper is a cross-cultural literature-reviewed study in nature by drawing textual evidence from previous Confucian research to provide basic exchange in education philosophy. The primary method utilized was an extensive review and analysis of existing literature from various sources (i.e. textbooks, published articles, expert discussions) 
on education philosophy, Confucius, Confucius' thought of education, Confucianism, Confucian values. Themes emerged from the synthesis of extant literature review as: Confucius' theory of 'no distinction in education'; the role, aim, contents, and pedagogical methods of education; and Confucius' idea of what a teacher should be. Insights drawn from Confucius' thought of education is integrated into these themes to provide practical implications for today's school leaders, teachers, and policymakers.

\section{THE LIFE OF CONFUCIUS AND HIS EDUCATIONAL CAREER}

Confucius was born probably in 551 BC in the State of Lu (in present-day Qufu City, Shandong Province), approximately one hundred years ahead of the Greek philosopher Socrates (469-399 BC). His name is Qiu and his cognomen is Zhongni. Confucius' ancestors were originally from the State of Song and then moved to the State of Lu, where many of the Zhou cultural heritage and values were preserved, due to political conflict between the Song aristocrats (see more in Guo, 2009; Palmer et al., 2001; Tan, 2013; Tang, 2013; Zhang, 2015).

Confucius grew up in a turbulent period, the Spring and Autumn and Warring States periods (770-476 BCE), in which various states always waged constant wars for centuries, making hundreds of people miserable. His father worked as a low-rank officer in the army of the State of Lu and died when Confucius was three years old, and then he was raised by his mother in poverty. When he reached adulthood, Confucius had to work hard to support his widowed mother and make a living for himself. Confucius worked numerous normal odd jobs first, i.e. chengtian (a petty official), before started teaching at the age of 30. Confucius returned to his hometown to establish a private school to wholeheartedly teach, develop his philosophy, collect ancient classic texts, and compose books. In his lifetime, numerous students came to study up to 3,000 disciples, including 72 prominent figures in history in ancient times, namely Yan Lu, Zeng Dian, Zigong, etc.

Confucius was widely known for his profound knowledge, intelligence, self-discipline, and morally good behavior (Palmer et al., 2001; Tan, 2013; Tang, 2013; Zhang, 2015). Due to his reputation in teaching, Confucius was promoted to work for the feudal government as sikou (minister of justice) at the age of 50. Because of the chaotic situation in the State of Lu, he and his disciples were forced into exile for almost 14 years. During their traveling through various states like vagabonds, his political ideas were not supported by the rulers of those states. Almost 20 years traveling for the purpose of teaching, disseminating, and practicing his educational and political philosophy, Confucius could not find a good ruler to serve. By the age of 68, Confucius returned to his hometown and spent his last few years in his hometown of Qufu teaching his disciples, writing, and sorting out the greatest Chinese classics of all time. Over 40 years of his teaching career, Confucius also composed a series of textbooks regarded as six Confucian classics such as the Book of Changes, the Book of History, the Book of Songs, the Book of Rites, the Spring and Autumn Annals, and the Book of Music (Guo, 2009). The great master passed away in $479 \mathrm{BC}$ of natural causes at the age of 72 . Confucius spent a lifetime making the greatest achievement in his career in education and with his distinguished disciples forming the Confucian school. Confucius devoted himself to education and taught people of all ranks without discrimination, deserving the honorific title 'the paragon of virtue for all generations' (Guo, 2009; Palmer et al., 2001; Tan, 2013; Tang, 2013; Zhang, 2015).

\section{CONFUCIUS' THEORY OF 'NO DISTINCTION IN EDUCATION'}

"Teaching should be given to all people without discrimination towards ranks and social status."

(The Analects, 'Duke Ling of Wei', cited in Guo, 2009, p.28) In his philosophy, Confucius opines that education is necessary for all people, regardless of class and status in society (Palmer et al., 2001; Tan, 2013). Education is the only means to enrich knowledge, cultivate personal and government morality, train people to behave properly, transform society, and maintain the social order. According to Confucius, education should be a universal right and not a privilege only to a group of people in society (Ames \& Rosemont, 1998; Guo, 2009; Tan, 2017). The theory of 'no class distinction in education' initiates a real revolution in ancient educational thought, making education available to the broad masses of ordinary people. This thought is the greatest of all, stressing the importance of education assess to people from all walks of life.

Confucius is credited as the first to popularize and universalize education, bringing opportunities to access to education for people regardless of whether aristocratic or ordinary and rich or poor (Bell \& Chaibong, 2003; Cooney et al., 1993; Zhao, 2013). Education was traditionally monopolized by the slave-owning class in those days. During the warring period, schools were controlled by the feudal governments and education was the privilege of the aristocrats. Thus, only the noble families could receive high academic education, and ordinary people or slaves did not have any chance to access education. 'From the very poorest upwards - beginning even with the man who could bring no better present than a bundle of dried flesh - none has ever come to me without receiving instruction' (cited in Guo, 2009, p.28). This quotation from Confucius indicates that anyone could become his student just with a modest gift, thus, enriching the social background of his initial students, e.g. from aristocrats or merchants' families to poor origin. Confucius offered education for people of all ranks and races and taught them without distinction. This philosophy broke through the previous tradition of the ancient aristocratic education and began the era of universal education in China. 
Moreover, the establishment of private education is also a great revolution in education, addressing 'no class discrimination in education' to all people from all walks of life for the first time as recorded in the human history (Guo, 2009). The fact that Confucius opened a private school for tutoring is a great revolution that paved the way for the general and comprehensive education to all people. This is regarded as a great contribution to the history of the education of mankind. With respect to the contribution, Confucius is honored as the great paragons for all generations (Cooney et al., 1993; Tang, 2015; Zhang, 2015). His idea of universal education is the philosophy that educational leaders should always endeavor to embrace so as to provide any person who wishes to study with equal opportunities for education.

\section{CONFUCIUS' THOUGHT OF THE ROLE OF EDUCATION}

The role of education for the state and society: Confucius addresses three key elements to prosper a country as population, wealth, and education. These three factors are inextricably interwoven as the development of the economy lays the foundation for the development of education. Moreover, Confucius (cited in Guo, 2009, p.31) states, 'Govern the people by regulations, keep order among them chastisements, and they will flee from you, and lose all self-respect. Govern them by moral force, keep order among them by ritual and they will keep their self-respect and come to you of their own accord.' Confucius stresses the importance of moral education to maintain social order and stability and consolidate political power (Ames \& Rosemont, 1998; Sim, 2009; Tan, 2013; Zhang, 2015). Though in his teachings, education is regarded as a political tool to defend the interests and positions of the aristocratic slave owners in society, the ancient lesson here drawn from historical evidence is that today's leaders must lend credence to education as one of the conditions that bring about social order, stability, and prosperity for a country.

The role of education for the cultivation of each individual: 'By nature, near together; by practice, far apart' (The Analects, 'Yang Huo', cited in Guo, 2009, p.32). As humans are basically born equal in terms of inherent qualities, then education, especially moral education, is the only force that makes the difference between individuals. Confucius (cited in Guo, 2009, p.34) also elaborates, 'Love of Goodness without love of learning degenerates into silliness. Love of wisdom without love of learning degenerates into utter lack of principle. Love of keeping promises without love of learning degenerates into villainy. Love of uprightness without love of learning degenerates into harshness. Love of courage without love of learning degenerates into mere recklessness.' Intrinsically, Confucius attaches great importance of education to the process of cultivating good qualities, i.e. mindfulness, kindness, cleverness, honesty, straightforwardness, bravery, and resoluteness (Tan, 2018; Tan, 2020; Wang, 2000; Woods \& Lamond, 2011; Yao, 2006).

\section{CONFUCIUS' THOUGHT OF THE AIM OF EDUCATION}

The aim of education is to train shi or to train people to become 'gentlemen' or 'gentleman scholars' (a respective title originally reserved for the ruling aristocrats) to commit to social responsibility and govern a country (Guo, 2009; Ng, 2009). According to Confucius, the quality of a true gentleman is associated with certain moral values such as diligence to his tasks, bravery, and loyalty to the rulers, and the mastery of the six arts, i.e. rites, music, archery, chariot-driving, history, and mathematics (Ames \& Rosemont, 1998; Lin, 2017; Tan \& Tan, 2016; Zhao, 2013). A true gentleman must cultivate in himself a sound morality and has the necessary ability to govern to bring peace, prosperity, and happiness to the broad masses of ordinary people (Sim, 2009; Wang, 2000; Yao, 2006). Confucius teaches, 'A gentleman studies, so that he may improve himself in the Way'; ( The Analects, 'Zizhang', cited in Guo, 2009, p.35-36) and 'Be of unwavering good faith, love learning, if attacked be ready to die for the good Way.' Especially, Confucius pays more attention to the role of morality in cultivating a person (Sim, 2009; Tan, 2013; Wang, 2000). Confucius' philosophy of morality cultivation concentrates on benevolence or humanity, the proper performance of rites, and forgiveness, attributing the ultimate goal of education. As for practicing sound morality, one is expected 'not to force upon others what one did not like' (Guo, 2009; Wang, 2000; Zhao, 2013). Thus, as per Confucius, welleducated and moral leaders should understand their positions and roles in the society to do no harm to the people, then educated and moral people should also understand their obligations and rights to perform and live in harmony with others (Ames \& Rosemont, 1998; Guo, 2009; Sim, 2009; Wang, 2000).

\section{CONFUCIUS' THOUGHT OF THE CONTENTS OF EDUCATION}

The goal and content of his education are aimed at teaching and training an ideal human being, in other words, a gentleman who is morally good and loyal to the feudal government to transform the society and maintain the order and status of the feudal regime. Confucius is highly dedicated to the education of human morality, considering it as the leading criteria of educational content. Yet, the ignorance of other competencies, especially scientific knowledge, is considered as a limitation in Confucius' instruction (Sim, 2009; Yao, 2006; Wang, 2000). Thus, although aiming at teaching knowledge, Confucius only taught history and literature subjects and paid little attention to science subjects (Guo, 2009; Tan, 2013).

Confucius' educational content focuses on the five qualities or ethic virtues of a gentleman: ren (benevolence or humanity), li (ceremony and etiquette of daily behavior), yi (righteousness), zhi (knowledge), and xin (integrity) (Ames \& Rosemont, 1998). Besides, Confucius advocates the teaching of liu yi (six arts): rites, music, archery, chariot- 
driving, history, and mathematics (Lin, 2017; Tan \& Tan, 2017). The educational subject matters could be divided into four faculties: virtue, politics, culture, and literature. These educational contents were really much diverse and comprehensive in scope compared with those in the previous dynasties, they brought about great effects in the context of transforming a chaotic, 'immoral' society into 'righteous' society of his time.

'The Master took four subjects for his teaching: culture, conduct of affairs, loyalty to superiors and the keeping of promises' ('Shu Er', cited in Guo, 2009, p.38). Truly, Confucius aims to teach morality and aspires to teach his disciples the humanistic value of ren or benevolence and educate people to love all mankind and live responsibly with their families, communities, and society (Ryu, 2010; Sim, 2009; Wang, 2000; Yao, 2006). Besides, Confucius advocates learning $l i$ or rites which trains people to become gentlemen and to live righteously (Guo, 2009). Then, it is of great significance to study history, literature, and other knowledge to carry out social and political tasks (Guo, 2009). During his teaching career, stressing the role of benevolence, righteousness, and loyalty in social life, Confucius also required his disciples to always train themselves (Kim, 2000; Ng, 2009; Tan, 2018; Woods \& Lamond, 2011). This is also a very reasonable viewpoint because in order to take the government posts, serve the people, and solve social and political affairs, people must first have high standards of morality. People must first cultivate themselves, have the responsibility with the family, then rule the country, and bring prosperity and happiness to the others.

\section{CONFUCIUS' THEORY ON PEDAGOGICAL METHODS}

\section{Individualized instruction according to students' aptitude and characteristics}

Confucius carefully observed each of his disciples to study their strengths and weaknesses, so he had a very specific understanding of the characteristics and personalities of each one (Guo, 2009; Guo, 2016; Shim, 2008). Thus, in the process of teaching and imparting knowledge, though he addressed the same content, he was able to individualize and tailor his teaching method for the good of each disciple (Ames \& Rosemont, 1998). As Confucius claims, 'To men who have risen at all above the middling sort, one may talk of things higher yet. But to men who are at all below the middling sort it is useless to talk of things that are above them' (cited in Guo, 2009, p.70). Confucius taught according to his students' abilities and gave different answers to the same question posed by different disciples. The ancient lesson of leaner-centered approach to learning reminds today's educators to always put students and their interests/needs as central to education process (Breuing, 2011; Dimitriadis \& Kamberelis, 2006; Hwang, 2013; McLaren \& Kincheloe, 2007).

\section{Active learning and effort in learning}

Confucius remarks, 'He who learns but does not think is lost. He who thinks but does not learn is in great danger' (cited in Guo, 2009, p.62). Students are encouraged to engage in various academic activities aimed to promote critical thinking and problem-solving skills. Confucius often asked his students open-ended questions with clues to stimulate his disciples' curiosity to a high level and let them time to think and ask as many questions as possible, and then taught them without weariness (Ames \& Rosemont, 1998). Confucius also emphasizes, 'Only one who bursts with eagerness do I instruct; only one who bubbles with excitement do I enlighten. If I hold up one corner and a man cannot come back to me with the other three, I do not continue the lesson' (cited in Guo, 2009, p.62). The willingness and eagerness of the students to learn encourage the commitment and devotion of the teacher to teach (Kim, 2000; Kim, 2003; McLaren \& Kincheloe, 2007).

\section{Do regular reviews and learn new things by restudying the old}

Confucius states, 'To learn and at due times to repeat what one has learnt, is that not after all a pleasure?' and 'He who by reanimating the old can gain knowledge of the new is fit to be a teacher' (cited in Guo, 2009, p.62). Thus, learning - reviewing - practicing are very important stages in the process of acquiring, consolidating, and applying knowledge (Guo, 2016; McLaren \& Kincheloe, 2007). This process is regarded as an on-going circle in which Confucius attaches great importance to life-long learning, addressing an important contribution of Confucius to education in terms of methods.

\section{Integration of Theory and Practice - Knowledge is closely associated with reality}

The ultimate goal of Confucius when teaching his disciples is to help them practice and apply the learned knowledge into life and become a gentleman or an exemplary feudal mandarin (Tan, 2013; Tang, 2015; Zhao, 2013). Confucius posits, 'A man may be able to recite the three hundred Songs; but, if when given a post in the government, he cannot turn his merits to account, or when sent on a mission to far parts he cannot answer particular questions, however extensive his knowledge may be, of what use is it to him?' (cited in Guo, 2009, p.63). Confucius opines that the real learning outcomes must be externally expressed through their daily actions, attitudes, and moral behaviors to 'illuminate their lived experiences' (Elliot \& Tsai, 2008; Zhao, 2013).

\section{CONFUCIUS' IDEA OF WHAT A TEACHER SHOULD BE}

\section{Set students an example and teach through both words and deeds}

As per Confucius (cited in Guo, 2009, p.71), 'If a man is correct in his own person, then there will be obedience without orders being given, but if he is not correct in his own person, there will not be obedience even though orders are given.' Confucius highlights that teachers have to set themselves as a good example to inspire students (Shim, 2008; 
Tan, 2017; Zhao, 2013). To do this, in his daily life, Confucius was eager to study and paid great attention to his behavior to greatly influence his disciples. Setting oneself as a model for the people to follow is the lesson and method he taught the mandarins and those who were planning to take the government posts (Guo, 2009). The mandarins were highly expected to be first morally good, love the people, show the loyalty to the rulers, and have the responsibility to the assigned tasks (Ames \& Rosemont, 1998; Palmer et al., 2001). These qualities are not very much different from our expectations for those in contemporary leadership position.

According to Confucius, 'If he [a man] cannot put himself aright, how can he hope to succeed in putting others right?' (cited in Guo, 2009, p.71). Truly, the teacher's personality and morality values have a great power of persuasion to the students. The students put their trust in the teacher and believe that what is taught is the truth and the guiding principles. Therefore, if teachers want to teach students something, they have to do it first and to prove it right. Confucius considers teaching by personal example very important (Cooney et al., 1993; Shim, 2008). Teachers are expected to not only have profound knowledge to be able to teach good students but also exhibit good personalities as an example for students to follow. Confucius' life and career are, thus, a testament to the example of a great teacher or sage (Cooney et al., 1993; Palmer et al., 2001). School leaders, teachers, and parents nowadays should pay attention to this educational principle, both in school and at home.

\section{Learn without flagging, love the students, and teach them unreservedly without growing weary}

Confucius is well-known for his ability 'to learn without flagging, to teach without growing weary' (cited in Guo, 2009, p.72). Confucius elaborates, 'As to being a Divine Sage or even a Good Man, far be it from me to make any such claims. As for unwearying effort to learn and unflagging patience in teaching others, those are merits that I do not hesitate to claim' (cited in Guo, 2009, p.71). Teaching is arguably regarded as one of the most important and valuable professions in society, thus, a great teacher should be committed to the on-going process of learning and enriching their knowledge, and whole-heartedly devoted and dedicated to the teaching career. Ultimately, Confucius posits that teachers are expected to show benevolence and wisdom to their students. Accordingly, a dedicated teacher should love the students unconditionally, pay attention to each student's condition, and understand them as much as possible.

\section{Pay great attention to diverse teaching methods}

Yan Yuan (cited in Guo, 2009, p.74), one of Confucius' students, says, 'Step by step the Master skillfully lures one on.' and 'Even if I wanted to stop [learning], I could not.' These remarks are explicitly a clear manifestation of the great of Confucius as an educator with excellent teaching skills. One of the explanations is Confucius' constant effort in practicing various teaching methods tailored to students' needs and socio-cultural circumstances. Confucius stresses the importance of using diverse appropriate teaching methods to inspire students during the process of imparting knowledge to them. More importantly, a great teacher knows how to encourage students to think actively, learn independently, and to behave morally.

\section{CONFUCIUS' THOUGHT OF MORAL EDUCATION AND LESSONS FOR TODAY'S EDUCATION}

The educational thought of Confucius is not free from some limitations. For instance, Confucius accepted the disciples from all walks of life without any class discrimination, and most of his disciples were ordinary people (Guo, 2009), but there were no women disciples. That questions the issue of educational equality as perceived by Confucius. Further, Confucius' preference for the authoritative practice of instruction is still a topic of criticism (Zhao, 2013). Besides, Confucius separated educational activities from material production activities, an important aspect of social life, only attaching great importance to spiritual and moral values (Ames \& Rosemont, 1998; Guo, 2009; Tan, 2003). This thought has received severe criticism from numerous Confucian scholars in the field. However, these limitations are minimal compared to his great contributions and overwhelming influence worldwide, both in the East and West (Bell \& Chaibong, 2003; De Mente, 2009; Guo, 2009; Pohl, 1999; Reid, 2000).

Confucius was born in the late Spring and Autumn Period, a period of great socio-cultural and political crisis and chaos, and rival states were waging war to conquer each other (Guo, 2009; Tan, 2013; Zhang, 2015). Through his educational philosophy and ideology, Confucius has a very strong political aspiration to help stabilize a chaotic society and create a hierarchical order in society. Confucius accords great importance to education as a driving force for personal and social transformation and development (Palmer et al., 2001; Tang, 2015; Zhang, 2015). Ultimately, Confucius himself initiates the idea of moral education as the key solution for human development and the current social transformation and stability (Sim, 2009; Tan, 2020; Wang, 2000). Confucius aspires to reestablish social order by considering the education of morality as a means of attaining social worth and status and stressing the importance of self-discipline, morally good and proper behavior, benevolence, loyalty, and obedience to hierarchy. Besides, the ultimate goal is to teach people to become gentlemen to build an ideal society in which people live in harmony, act by virtue, show benevolence to others, and treat each other with morality. It can be said that the philosophy, aims, content, and methods of education of Confucius express the idea of closeness to the broad masses of people and for the good of the people. Besides, Confucius' thought provides a solid foundation for generations of his disciples to inherit and develop the core values of Confucianism that has a great influence on almost all education systems in the East since the Spring and Autumn Period. Thus, in the history of Eastern educational philosophy, Confucius is 
regarded as a pioneer in developing a relatively systematic and comprehensive content and methodology of education, of which many educational principles are progressive and advanced, especially still valid today.

Today, when dismissing feudal principles in Confucius' thought, numerous Confucian scholars and educators worldwide have studied and appreciated the persistent values and principles in his views (Beretta et al., 2017; De Mente, 2009; Tamney \& Chiang, 2002). Today's schools should leverage these values especially in moral education for the younger generation. Accordingly, Confucius attaches great importance to the education of traditional cultural values and moral virtues, as well as to apply and practice those traditional values to the present and in the future. Therefore, though faced unprecedented changes, today's schools cannot ignore their missions of moral education of preparing future leaders. In the process of education and training, young generations need to be taught with the traditional cultures and values such as patriotism, studiousness, bravery, benevolence and humanity, and righteousness, etc., for future transformation and holistic development. Especially for moral self-cultivation, the ethic virtues of benevolence and righteousness of Confucianism teach young generations to become 'gentlemen' to treat others with mindfulness, kindness, generosity, and tolerance (Halstead, 2010; Hyde \& LaPrad, 2015; Sim, 2009; Wang, 2000). Besides, Confucianism has a positive and great influence on the moral education of awareness of self-discipline and sense of responsibility for the family and society (Bell \& Chaibong, 2003; Guo, 2016; Tang, 2015). Despite the cultural differences of East and West, the present paper opines that the educational philosophy developed by Confucius himself, his disciples, and many generations of followers through the ages has created a great and powerful legacy of a holistic view of learning and education and its relevancy not only for China but the contemporary society to study, apply, and practice.

\section{CONCLUSION}

Based on Confucius' teachings as recorded in the Analects and synthesized from prior studies, the present paper gains insights into Confucius' educational thought and particularly his emphasis on the cultivation of moral education during uncertain times. Ultimately, Confucius' teachings have the universal concern for the well-being of the entire humanity. It is strongly believed that the progressive viewpoints in Confucius' educational thought is not only valuable in feudal society, but also of great value to today's education and training for the good of all mankind.

Further, extant research on educational thought of great thinkers through the ages is helpful in addressing guidelines and policies to reform and innovate education and training, especially in the era of market and knowledge economy and international integration. These guidelines and policies should be based on inheriting and promoting the moral values in the history of human civilization. Thus, the extensive research and selective application of Confucius' educational thought will be of great significantly universal value to any education system in the modern world.

\section{REFERENCES}

Ames, R. T., \& Rosemont, H. Jr. (1998). The analects of Confucius: A philosophical translation. Ballantine Books.

Bell, D. A., \& Chaibong, H. (2003). Confucianism for the modern world. Cambridge: Cambridge University Press.

Beretta, S., Berkofsky, A., \& Zhang, L. (2017). Understanding China today: An exploration of politics, economics, society, and international relations. Springer International Publishing.

Breuing, M. (2011). Problematizing critical pedagogy. International Journal of Critical Pedagogy, 3(3), 2-23.

Cooney, W., Cross, C., \& Trunk, B. (1993). From Plato to Piaget: The greatest educational theorists from across the centuries and around the world. Lanham, MD: University Press of America.

De Mente, B. L. (2009). The Chinese mind: Understanding traditional Chinese beliefs and their influence on contemporary culture. Tuttle Publishing.

Dimitriadis, G., \& Kamberelis, G. (2006). Theory for education. New York, NY: Routledge.

Elliott, J., \& Tsai, C. T. (2008). What might Confucius have to say about action research? Educational Action Research, 16(4), 569-578.

Guo, Q. (2009). A history of Chinese educational thought. China, Bejing: Foreign Languages Press.

Guo, L. (2016). Research of Confucianism education method in Chinese college students' ideological and political education. Creative Education, 7, 1051-1055.

Halstead, J. M. (2010). Moral education. In C. S. Clauss-Ehlers (Ed.), Encyclopaedia of cross-cultural school psychology (pp. 630-631). Springer.

Hwang, K. (2013). Educational modes of thinking in Neo-Confucianism: A traditional lens for rethinking modern education. Asia Pacific Education Review, 14(2), 243-253.

Hyde, A. M., \& LaPrad, J. G. (2015). Mindfulness, democracy, and education. Democracy \& Education, 23(2), 1-12.

Kim, K. H. (2000). A Confucian perspective of self-learning. In. G. A. Straka (Ed.), Conceptions of self-directed learning (pp. 109-125). Berlin, Germany: Waxmann.

Kim, H. K. (2003). Critical thinking, learning and Confucius: A positive assessment. Journal of Philosophy of Education, $37(1), 71-87$.

Lin, Y. (2017). Confucius's view of learning. Educational Philosophy and Theory, 50(13),1180-1191.

McLaren, P., \& Kincheloe, J. L. (2007). Critical pedagogy. New York, NY: Peter Lang. 
Ng, R. M.-C. (2009). College and character: What did Confucius teach us about the importance of integrating ethics,character, learning, and education? Journal of College and Character, 10(4), 1-7.

Palmer, J., Bresler, L., \& Cooper, D. E. (Eds.). (2001). Fifty major thinkers on education: From Confucius to Dewey. London, England: Routledge.

Pohl, K. H. (1999). Chinese thought in a global context: A dialogue between Chinese \& Western philosophical approaches. Leiden, Netherlands: Brill.

Reid, T. R. (2000). Confucius lives next door: What living in the East teaches us about living in the West. New York, NY: Vintage.

Ryu, K. (2010). The teachings of Confucius: Reviving a humanistic adult education perspective. International Journal of Continuing Education and Lifelong Learning, 2(2), 11-28.

Shim, S. H. (2008). A philosophical investigation of the role of teachers: A synthesis of Plato, Confucius, Buber, and Freire. Teaching and Teacher Education, 24(3), 515-535.

Sim, M. (2009). Dewey and Confucius: On moral education. Journal of Chinese Philosophy, 36(1), 85-105.

Tamney, J. B., \& Chiang, L. H. (2002). Modernization, globalization, and Confucianism in Chinese societies. Westport: Praeger Publishers.

Tan, C. (2013). Confucius. Bloomsbury.

Tan, C. (2018). To be more fully human: Freire and Confucius. Oxford Review of Education, 44(3), 370-382.

Tan, C. (2017). Confucianism and education. In G. Noblit (Ed.), Oxford research encyclopedia of education (pp. 1-18). New York: Oxford University Press.

Tan, C. (2019). Rethinking the concept of mindfulness: A neo-Confucian approach. Journal of Philosophy of Education, $53(2), 359-373$.

Tan, C. (2020). Mindfulness and morality: Educational insights from Confucius. Journal of Moral Education, 1-12.

Tan, C., \& Tan, L. (2016). A shared vision of human excellence: Confucian spirituality and arts education. Pastoral Care in Education, 34(3), 156-166.

Tang, Y. (2015). Confucianism, Buddhism, Daoism, Christianity and Chinese Culture. Springer-Verlag Berlin Heidelberg. Wang, Y. P. (2000). The Confucian conception of a moral person. Hong Kong, China: University of Hong Kong Press.

Woods, P. R., \& Lamond, D. A. (2011). What would Confucius do? Confucian ethics and self-regulation in management. Journal of Business Ethics, 102(4), 669-683.

Yao, X. Z. (2006). Learning to become good. In A. Ruggiero (Ed.), Confucianism. Detroit, MI: Greenhaven Press.

Zhang, Q. (2015). An introduction to Chinese history and culture. Springer, China Academic Library.

Zhao, J. (2013). Confucius as a critical educator: Towards educational thoughts of Confucius. Frontiers of Education in China, 8(1), 9-27.

Publisher's note: Science Impact Publishers remain neutral with regard to jurisdictional claims in published maps and institutional affiliations.

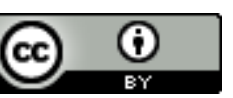

Open Access This article is licensed under a Creative Commons Attribution 4.0 International License, which permits use, sharing, adaptation, distribution and reproduction in any medium or format, as long as you give appropriate credit to the original author(s) and the source, provide a link to the Creative Commons license and indicate if changes were made. The images or other third-party material in this article are included in the article's Creative Commons license, unless indicated otherwise in a credit line to the material. If material is not included in the article's Creative Commons license and your intended use is not permitted by statutory regulation or exceeds the permitted use, you will need to obtain permission directly from the copyright holder. To view a copy of this license, visit https://creativecommons.org/licenses/by/4.0/.

(C) The Author(s) 2020 